than knowledge: it is often the means whereby we gain more knowledge' (p. 364). Probably the writer goes too far in limiting Christian wisdom to ethical conduct, but he is to the point when he urges that the new knowledge in psychology and sociology as being largely ethical in nature claims the 'earnest attention' of the Christian pastor (p. 377).

On the other hand, in spite of many helpful passages, it must be said that the combination of commentary, discussion of words, application, and exhortation has produced a book which is exceedingly difficult to read with sustained interest.

The ideas often lack freshness, and, when suggestive of originality, are insufficiently developed. It is difficult to gather any definite inspiration from the book, or to feel that the method adopted really throws much new light upon St Paul and the secrets of his success.

C. Barrow in Furness.

\title{
CODEX 'ALEXANDRINUS'.'
}

The Trustees of the British Museum have begun to issue a new complete photograph of the famous Codex Alexandrinus (A) in reduced facsimile, whereby scholars will be able to acquire an accurate representation of this great $\mathrm{MS}$ at a much lower cost than that of the full-size photograph, published in $1879-83$. The actual photograph of each page in this new publication measures about 8 in. $\times 6 \frac{1}{2}$ in. The printing of the plates (executed by the University Press, Oxford) is very clear and legible, when the state of the MS is considered, and Dr Kenyon writes the Introduction.

The present volume contains the New Testament and Clementine Epistles, but the other volumes are promised in due course. This therefore seems an appropriate time to express the hope that in the Introduction to the Old Testament volumes the mediaeval history of Codex A will be fully investigated, with a view to determine how far it deserves to be called 'Alexandrian' at all. Every one knows that it was formerly in the possession of Cyril Lucar, Patriarch of Alexandria (till 1621 ), and afterwards of Constantinople $\left(1621-163^{8}\right)$. It was given

1 The Codex Alexandrinus in reduced photographic facsimile (vol. i, New Test. and Clementine Epp.). Printed by order of the Trustees, 19og. 
to Charles I through Sir Thomas Roe, then British Ambassador at Constantinople, but, as Dr Kenyon observes, "the history of the Codex Alexandrinus, before it passed from the hands of Cyril Lucar to Sir Thomas Roe, is more obscure'. As a matter of fact, the mediaeval history of the Codex, which is repeated in so many Introductions to the Greek Testament and to palaeography, is based upon an Arabic Note at the foot of the first page of Genesis. It seems, therefore, worth while to consider this Note a little more closely, all the more since it has not been made the subject of any enquiry since Professor Nicoll of Oxford interpreted it for Baber's edition of A in $182 \mathrm{I}$. The Note consists of three lines of very bad Arabic writing, with a cross at the side. The vellum also is stained and lacerated. I read as follows :-

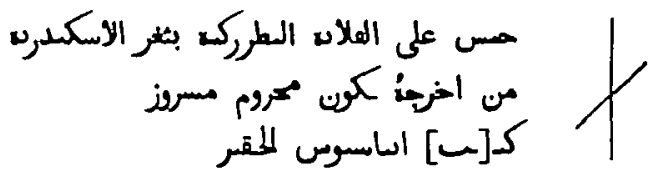

That is, supplying the points,

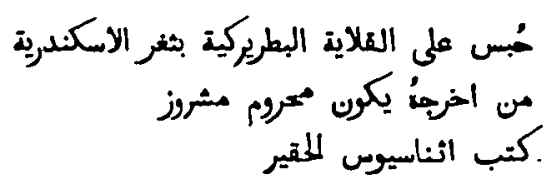

(I) Bound to the Patriarchal Cell in the Fortress of Alexandria.

(2) He that lets it go out shall be cursed and ruined.

(3) The humble Athanasius wrote (this).

'Cell ' (تلاية) is the regular term for the Patriarchal residences, both Malkite and Jacobite, in Cairo. Both dignitaries considered themselves Patriarchs of Alexandria, successors of the great Athanasius and Cyril : the first line of this inscription means that the MS, when the Note was written, belonged to the Patriarchal Library in Cairo, and as we find it in the possession of Cyril Lucar, the Greek Patriarch, it refers presumably to the Library of the Malkites. The last word of line (2) is indistinct, but it obviously means 'cursed' or 'punished': Nicoll read jرen, but I think the second letter looks more like n. For the third line Nicoll read اناناسيرس للمقير, thinking the first letter was Alif, but it is certainly $R a f^{1}$; in fact, previous to Nicoll the line was read سابس (i. e. 'Sabas wrote this'). There is a hole after the Kaf, but the next letter must be $b, t, n$, or $y$. I read the proper name Athanasius, as Nicoll does: the spelling as I decipher the word corresponds with the usual spelling.

1 It is formed exactly like the Kaf of 1 , in the Thekla inscription on the urso of the fly-leaf. 
It is usual to identify 'the humble Athanasius' with Athanasius III, Patriarch of Alexandria about $\mathrm{r}_{3} 00$. But is there any reason why this scribe should be a Patriarch at all? Do not Patriarchs usually indicate that 'by Divine permission' they are Patriarchs? Certainly this is the case with 'Michael by the mercy of God Patriarch of Antioch', who wrote his name and anathema in the thirteenth-century codex of Eutychius's Annals now in the British Museum. ' Similarly 'the poor Macarius' (الفقير ماكاريوس) never fails to add the territorial title 'of Antioch', be being Patriarch, every time that he writes his name in B.M. Addit. 9965.'

But if 'the humble Athanasius' who wrote the Note in Codex A be not a Patriarch of Alexandria, some curious consequences follow. The argument hitherto accepted has run thus: Athanasius who wrote the Note signed his name with a cross and says the Codex was an heirloom of the Patriarchal Library of Alexandria, therefore Athanasius was a Patriarch of Alexandria ; the only Patriarch Athanasius who is late enough is Athanasius III, therefore the writer of the Note is Athanasius III, therefore the Codex was in Alexandria (or rather, in Cairo) about the year I300; therefore it really is Egyptian in origin, and has always been kept in Egypt.

It is true that 'J. J. Wetstein (Nov. Test. Gr. i 10) quotes a letter of his uncle, J. R. Wetstein, written in 1664 , in which he states, on the authority of Matthaeus Muttis, a deacon of Cyril's, that the MS was found at Mt. Athos', as Dr Kenyon faithfully reports (p. 7, note). Dr Kenyon, however, goes on to say that very little weight can be attached to this statement, because 'clearly the MS was at Alexandria about 1300'. But what puts the Arabic Note we have been considering into the fourteenth century, except the theory that it must have been written by a Patriarch named Athanasius? Is it not more likely that Athanasius was some person of Cyril Lucar's staff, who had charge of his Library?

If we accept Matthaeus Muttis's statement, we may suppose that Cyril Lucar, then Patriarch of Alexandria, got hold of Codex A at Athos in I6r6. The Codex passed into the Patriarch's Library, but as he himself had acquired it, he felt himself at liberty to take it with him when he was translated to Constantinople in $162 \mathrm{I}$, and afterwards to

1 Cotton Caligula A iv : see Cureton's Catalogue (1846) p. 49.

- Cureton's Catalogue pp. 4I-45; see also the autograph of Athanasius, Bishop of $\mathrm{Kara}$ in $\mathrm{II}^{36}$ (Wright CBM I99). My friend Mr E. H. Minns has further drawn my attention to the Patriarchal autographs collected by $\mathrm{N}$. Likhatcheff in the Trans. Imp. Russ. Archneol. Society of St Petersburg (vol. iv, 1907). These Greek documents, which include a letter from Cyril Lucar himself, shew that the shape of the cross in the Arabic Note in Cod. A was in use about 1650. 
present it to the King of England.' If Codex A came from Athos, that means it originally came not from Egypt, but from Constantinople. In a word, it represents a Constantinopolitan, not an Egyptian, text of the Greek Bible.

So far as I know, there is nothing in Codex $A$ to indicate that it was ever in Egypt before 1616. The only Arabic writing it contains is ( $I$ ) the Thekla inscription " (2) the Athanasius inscription; (3) the pagination, which goes through the whole Codex ; $(4)$ two notes in the margin of Wisdom, viz. دوم اللمعس i. e. 'Friday', opposite Wisd. ii 12, and الغصم 'Easter', opposite Wisd.v I. All this seems to me to be contemporary, if not by the same hand. I venture to think it rests with those who still support an Egyptian provenance for Codex A to shew that these Notes are not contemporary with Cyril Lucar. All the other lectionary-marks, some of them quite late, are in Greek, as also is the very ill-spelt sentence written in the corner of fol. $605 r$, and repeated on the lower margin of the opposite page. As far as I can read it, it runs :-

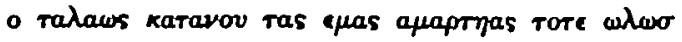

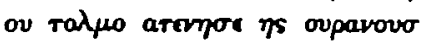

In any case, it appears to be the work of some one who lived about the tenth century, and had more piety than grammar. It has nothing to do with the text, which is a page of the Song of Songs. The Greek lectionary marks, scattered about various Books of the O. T,; look to me much later, but some of the marginal corrections, e. g. in 2 Chron. xxxii 23, appear to be of the tenth to the twelfth century.

All this is quite inconclusive : let us hope that the future volumes of the new facsimile will do something to clear the matter up. The main object of this Note has been simply to call attention to the extreme slenderness of the material, out of which the generally accepted history of the Coder 'Alexandrinus' has been constructed.

\section{F. C. Burkitt.}

1 It is worth noting that the ansthema was not erased, when the Codex was presented to Sir Thomas Roe. Contrast the case of the MS now numbered CUL Gg. 5. 27, an Arabic copy of the Gospels (dated 1285) which Cyril Lucar gave in 1618 to David de Wilem. In this the old notes of ownerahip have been carefully destroyed.

'د i.e. 'They relate that this book is in the handwriting of Thekla the Martyr'. This is written on the orrso of the Ay-leat, facing Gen. $i$, and appears to me to be in the same hand as the Athonagius inseription. 